\section{Prenatal diagnosis of an isolated Coronary arterial fistula}

Congenital coronary artery fistulas (CAF) are rare malformations which can be complicated by hemodynamically relevant intracardiac shunts, endocarditis, myocardial infarction, thromboemboly or coronary aneurysms and rupture. The incidence of isolated coronary fistula is 1:50000 live birth (Schumacher G et al. Thorac Cardiovas Surg 1997; 45: 287-294). The left, right or both coronary arteries may be involved. The fistulas drain mainly to the right heart side (92\%) with $41 \%$ to the right ventricle (Schumacher G et al. Thorac Cardiovas Surg 1997; 45: 287-294). We report the exceptional prenatal diagnosis of a fistula of the left coronary artery to the right ventricle at 26 weeks of gestation.

A 27 years old gravida 3 para 2 was referred for an expert follow up of an atypical ventricular septal defect suspected during routine obstetrical screening ultrasound. The 4-chamber view showed an aneurysmatic structure at the apex of the ventricular septum ( $\odot$ Fig. 1) shunting into the right ventricle as visualized by color Doppler (๑ Fig.2). Closer examination revealed a tortuous structure draining into the distal part of the aneurysma and connected to an enlarged ramus interventricularis of the left coronary artery ( $\bullet$ Fig. 3 ). The short axis view showed a dilated origin

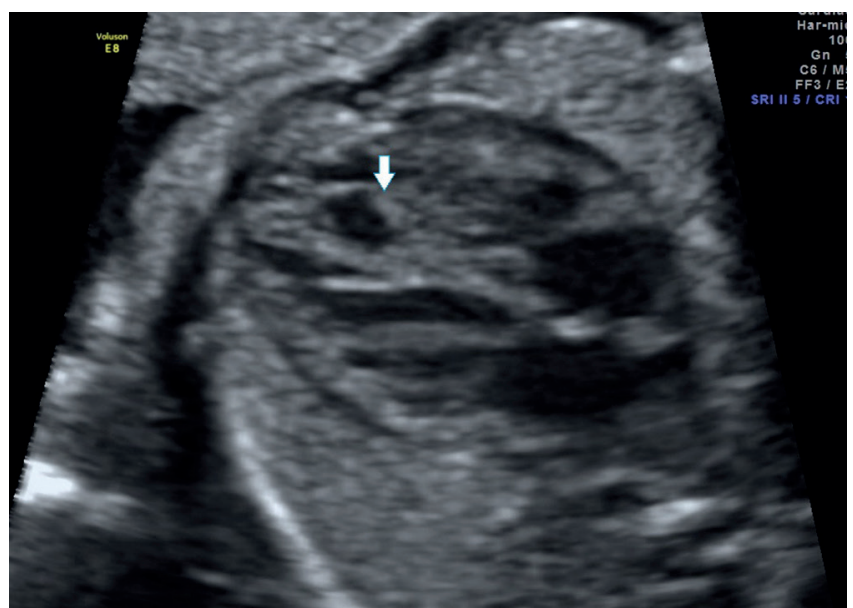

Fig. 1 Aneurysmal dilation at the apex of the ventricular septum Abb. 1 Aneurysmale Dilatation am Apex des Kammerseptums

of the left coronary artery. The right coronary artery was normal. On color flow imaging there was bidirectional forward and backward flow through the dilated ramus interventricularis. Other heart structures, dimensions and flow velocities were normal according to gestational age. Fetal growth, amniotic fluid volume as well as Doppler velocity wave forms of umbilical vein, ductus venosus, inferior caval vein and middle cerebral artery were normal as well. After the diagnosis of a fistula from the left coronary artery to the right ventricle in a structurally normal heart close ultrasound monitoring revealed no increase in size of the fistula or other complications. The child was delivered by caesarean section at 38 weeks of gestation in a tertiary pediatric cardiology centre. The birthweight was $3180 \mathrm{gr}$, length $48 \mathrm{~cm}$, Apgar score 8-9-9. A cardiac examination showed no signs of heart failure, but an hyperactive praecordial impulse and a 3/6 systolic mur-

\section{Pränatale Diagnose von isolierten koronaren arteriellen Fisteln}

Angeborene koronare arterielle Fisteln (CAF) sind seltene Fehlbildungen, bei denen als Komplikation hämodynamisch-relevante intrakardiale Shunts, Endokarditis, Herzinfarkt, Thromboembolie und koronare Aneurysmen und deren Ruptur auftreten können. Die Inzidenz isolierter koronarer Fisteln beträgt 1 pro 50000 Lebendgeburten (Schumacher $\mathrm{G}$ et al. Thorac Cardiovas Surg 1997; 45: 287-294). Es können sowohl die linke, die rechte oder aber beide Koronararterien davon betroffen sein. Die Fisteln drainieren vor allem zur rechten Herzseite (92\%), davon $41 \%$ zum rechten Ventrikel (Schumacher G et al. Thorac Cardiovas Surg 1997; 45: 287-294). Wir berichten über die ungewöhnliche pränatale Diagnose einer Fistel von der linken Koronararterie zum rechten Ventrikel in der 26. Schwangerschaftswoche.

Eine 27-jährige Schwangere (3 Gravida 2 Para) wurde zur Nachuntersuchung beim Spezialisten einbestellt, da sich im RoutineUltraschallscreening beim Frauenarzt der Verdacht auf einen atypischen ventrikulären Septumdefekt ergab. Der Vierkammerblick zeigte eine aneurysmatische Struktur am Apex des Kammerseptums ( $\bullet$ Abb. 1) mit Shunt zum rechten Ventrikel, wie im Farbdoppler zu sehen ist ( $\bullet$ Abb. 2). Die genauere Untersuchung zeigte eine gewundene Struktur, die in den distalen Bereich des Aneurysma drainierte und mit dem vergrößerten Ramus interventricularis der linken Koronararterie verbunden war ( $\bullet$ Abb. 3). Der Kurzachsenblick zeigte einen erweiterten Ursprung der linken Koronararterie. Die rechte Koronararterie war normal. Im Farbdoppler gab es eine bidirektionale Vorwärts- und Rückwärtsströmung durch den erweiterten Ramus interventricularis. Die übrigen Herzstrukturen, Dimensionen und Flussgeschwindigkeiten waren für das entsprechende Gestationsalter normal.

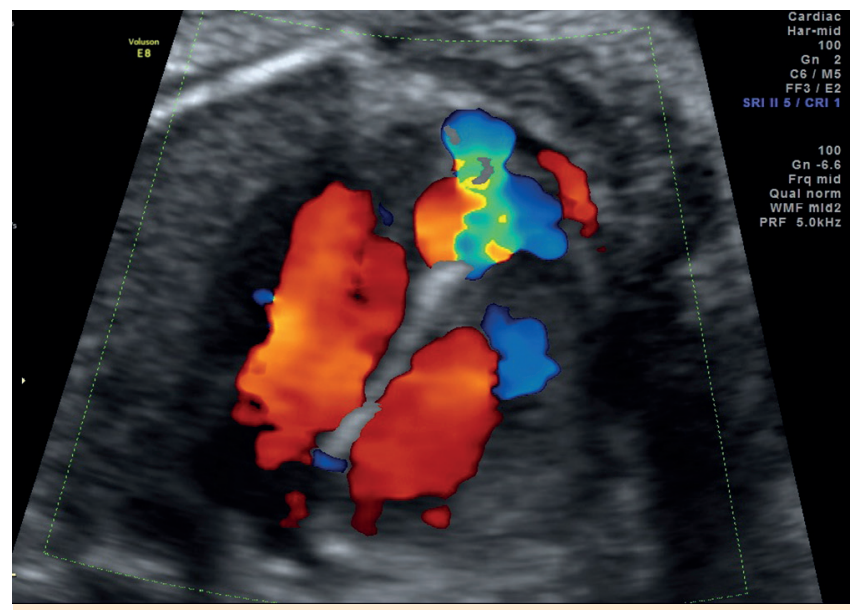

Fig. 2 Coronary artery fistulae shunting into the right ventricle visualized by color Doppler

Abb. 2 Koronare arterielle Fistel mit Shunt zum rechten Ventrikel ist im Farbdoppler zu sehen.

Das fetale Wachstum, die Fruchtwassermenge sowie die Dopplerflüsse von V. umbilicalis, Ductus venosus, V. cava inferior und A. cerebri media waren ebenfalls im Normbereich. Nach der Dia- 


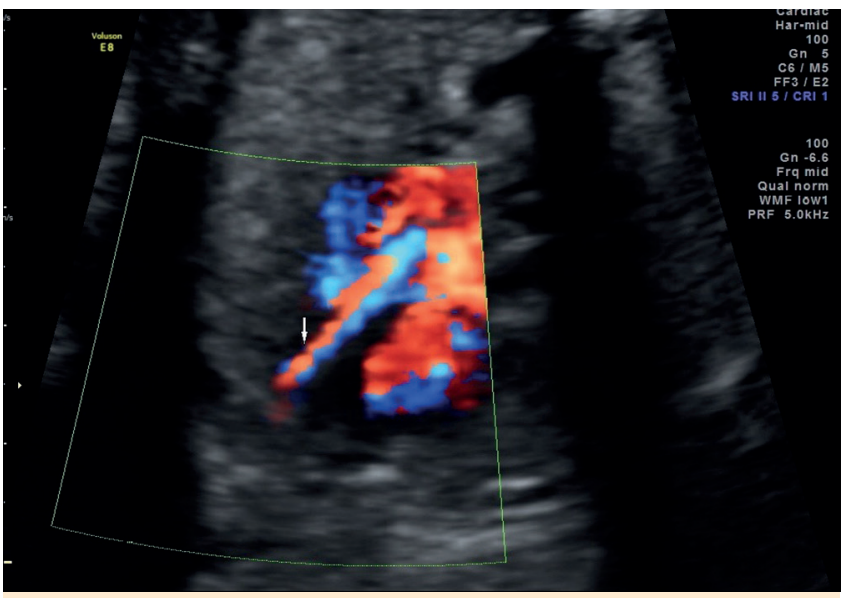

Fig. 3 Enlarged ramus interventricularis of the left coronary artery Abb. 3 Vergrößerter Ramus interventricularis der linken Koronararterie.

mur at the left sternal border with irradiation to the left axilla. ECG was normal. Echocardiography showed a dilated left coronary artery of $3 \mathrm{~mm}$ with a ramus interventricularis of $5 \mathrm{~mm}$ which ended in an aneurysmatic dilatation of $11 \times 9 \mathrm{~mm}$ at the apex of the heart. The aneurysma was connected to the right ventricle without any restriction on color flow. Doppler ultrasound revealed a bidirectional flow in the ramus interventricularis with forward flow in the diastole and backward flow in the systole. There were physiologic elevation of pulmonary pressure, PDA and PFO. Clinical follow up was uneventful and a echocardiography at the age of 1 week showed an increase of the diameter of the ramus interventricularis to $7 \mathrm{~mm}$ with now continuous forward flow in color Doppler and tortuous draining to the aneurysm. A non restrictive connection of the aneurysm to the cavity of the right ventricle was found and there were still indirect signs of elevated pulmonary pressure. Aspirine $(5 \mathrm{mg} / \mathrm{kg} / \mathrm{d})$ was administered. Follow up at 4, 8 and 12 weeks of age still revealed no complications. On echocardiography the only change was a normalisation of pulmonary pressure with restrictive flow from the coronary fistula to the right ventricle. Due to these findings it was decided to postpone any further diagnostic procedure, embolization or surgery to allow the child to grow to an optimal weight for intervention.

Patients with isolated coronary artery fistula have few symptoms but serious complications like congestive heart failure, ischaemic events from coronary steal, bacterial endocarditis and aneurysmatic as well as thromboembolic events have been reported (Schumacher G et al. Thorac Cardiovas Surg 1997; 45: 287-294, Davis JT et al. Ann Thorac Surg 1994; 58: 760-763). Intrauterine diagnosis has been shown to be helpful for planning of the perinatal management and prevention of lifethreatening complications during the neonatal period (Sharland GK et al. Heart 1996; 76: 79-81).

Coronary artery fistulas can be detected prenatally mainly when they are large (Sharland GK et al. Heart 1996; 76: 79-81). The coronary blood flow can be demonstrated by color Doppler in the 4 chamber, 5 chamber, short axis and long axis view of left outflow tract and ascending aorta (Gembruch U, Baschat AA. Ultrasound Obstet Gynecol 1996; 7: 10-16, Mielke G et al. Ultrasound Obstet Gynecol 2002; 19: 412-415). In our case 2D echocardiographic imaging showed the dilated left coronary artery with tortuousity in its distal part and drainage to an aneurysma leading gnose einer Fistel von der linken Koronararterie zum rechten Ventrikel in einem strukturell normalen Herzen zeigte die engmaschige Ultraschallüberwachung weder eine Zunahme der Fistelgröße noch andere Komplikationen. Die Entbindung des Kindes erfolgte in der 38. Schwangerschaftswoche per Kaiserschnitt in einem pädiatrisch-kardiologischem Tertiärzentrum. Das Geburtsgewicht betrug $3180 \mathrm{~g}$, die Länge $48 \mathrm{~cm}$ und der ApgarScore 8-9-9. Eine kardiologische Untersuchung ergab keine Hinweise auf Herzschäden, es wurden aber ein hyperaktiver präkordialer Impuls und ein 3/6 Systolikum am linken Rand des Brustbeins mit Ausstrahlung zur linken Axilla festgestellt. Das EKG war im Normbereich. Die Echokardiografie zeigte eine erweiterte linke Koronararterie von $3 \mathrm{~mm}$ mit einem Ramus interventricularis von $5 \mathrm{~mm}$, die in einer $11 \times 9 \mathrm{~mm}$ großen aneurysmatischen Dilatation am Apex cordis endete. Das Aneurysma war mit dem rechten Ventrikel verbunden, ohne irgendeine Restriktion im Farbdoppler. Die Dopplersonografie zeigte eine bidirektionale Strömung im Ramus interventricularis mit Vorwärtsströmung in der Diastole und Rückwärtsströmung in der Systole. Es gab eine physiologische Erhöhung des pulmonalen Drucks (PDA, PFO). Der klinische Verlauf war unauffällig und die Echokardiografie im Alter von 1 Woche zeigte eine Vergrößerung des Durchmessers des Ramus interventricularis auf $7 \mathrm{~mm}$ mit einer jetzt beständigen Vorwärtsströmung im Farbdoppler und dem gewundenen Drainieren zum Aneurysma. Es wurde eine nicht-restriktive Verbindung des Aneurysma mit der Kavität des rechten Ventrikels entdeckt und es bestanden noch indirekte Zeichen für pulmonalen Hochdruck. Aspirin (5 mg/ kg/ d) wurde verabreicht. Die Nachuntersuchung im Alter von 4, 8 und 12 Wochen entdeckte noch keine Komplikationen. Die einzige Veränderung in der Echokardiografie war die Normalisierung des pulmonalen Drucks mit einer restriktiven Strömung von der koronaren Fistel in den rechten Ventrikel. Aufgrund dieser Befunde wurde entschieden, alle weiteren diagnostischen Prozedere, Embolisierung oder Operation zu verschieben, damit das Kind wachsen kann und somit ein optimales Gewicht für einen Eingriff bekommt.

Patienten mit einer isolierten koronaren arteriellen Fistel zeigen geringe Symptomatik, es wurde jedoch von schweren Komplikationen wie Herzinsuffizienz, ischämische Vorgängen durch den koronaren Steal-Effekt, einer bakteriellen Endokarditis und von aneurysmatischen sowie thromboembolischen Geschehen berichtet (Schumacher G et al. Thorac Cardiovas Surg 1997; 45: 287-294, Davis JT et al. Ann Thorac Surg 1994; 58: 760-763). Die intrauterine Diagnose hat sich für das Geburtsmanagement und zur Vermeidung lebensbedrohlicher Komplikationen in der Neugeborenenperiode als hilfreich erwiesen (Sharland GK et al. Heart 1996; 76: 79-81)

Koronare arterielle Fisteln können pränatal vor allem dann entdeckt werden, wenn sie groß sind (Sharland GK et al. Heart 1996; 76: 79-81). Der koronare Blutfluss kann im Farbdoppler im Vierkammer-, Fünfkammer-, Kurz- und Langachsenblick des linken Ausflusstraktes und der aufsteigenden Aorta gezeigt werden (Gembruch U, Baschat AA. Ultrasound Obstet Gynecol 1996; 7: 10-16, Mielke G et al. Ultrasound Obstet Gynecol 2002; 19: 412415). In unserem Fall zeigte das Bild der 2D-Echokardiografie die dilatierte linke Koronararterie mit Verwindungen im distalen Teil und Drainage ins Aneurysma, die zur Verdachtsdiagnose isolierte koronare arterielle Fistel führte. Der Farbdoppler und der gepulste Doppler mit der typischen bidirektionalen Vorwärts- und Rückwärtsströmung durch die dilatierte Koronararterie und der 
to the suspicion of coronary artery fistula. Color Doppler and pulsed wave Doppler with typical bidirectional forward and backward flow through the dilated coronary artery and shunting of the aneurysma to the right ventricle allowed to confirm the diagnosis.

Small fistulas may close spontaneously but large fistulas may enlarge in size and lead to severe complications (Sharland GK et al. Heart 1996; 76: 79-81, Hung JH et al. J Ultrasound Med 2006; 25 : 1075-1078). In such cases early intervention is recommended. Surgical closure used to be the standard treatment with mortality ranging from 0-4\% (Schumacher $\mathrm{G}$ et al. Thorac Cardiovas Surg 1997; 45: 287-294). Today transcathetric non surgical embolisation is the preferred option (Sharland GK et al. Heart 1996; 76: 79-81). Before intervention exact visualization of the fistula by angiography, CT or MRI may be necessary (Schumacher G et al. Thorac Cardiovas Surg 1997; 45: 287-294, Tsubata S et al. Cardiol Youn 1998; 8: 250-252).

In this case close prenatal and postnatal monitoring with serial cardiac scans showed, that the fistula did not enlarge and that there was no significant left to right shunting. There were no signs of right ventricular enlargement, pulmonary pressure dropped to normal values after 4 weeks of age and there was a restrictive flow from the fistula to the right ventricle. Moreover the child did not present any symptoms of myocardial ischemia. Therefore it seemed appropriate to postpone closure of the fistula until the child has grown to an optimal weight. In Conclusion, this case shows an exotic congenital cardiac defect highlighting the power of detailed ultrasound evaluation during routine scan and followed up by specialised centres. With increased experience and improved devices and technique rare but relevant small fetal abnormalities are detectable prenatally and may help to prevent postnatal compilatations.An
Shunt des Aneurysmas und dem rechten Ventrikel erlaubte die Diagnosestellung.

Kleine Fisteln können sich spontan verschließen, aber große Fisteln können an Größe zunehmen und zu schweren Komplikationen führen (Sharland GK et al. Heart 1996; 76: 79-81, Hung JH et al. J Ultrasound Med 2006; 25: 1075-1078). In diesen Fällen wird ein früher Eingriff empfohlen. Der chirurgische Verschluss war bisher das Standardverfahren und hatte Mortalitätsraten von 0-4\% (Schumacher G et al. Thorac Cardiovas Surg 1997; 45: $287-$ 294). Heutzutage ist die nicht chirurgische Transkatheterembolisierung die bevorzugte Methode (Sharland GK et al. Heart 1996; 76: 79-81). Vor dem Eingriff sollte die genaue Visualisierung der Fistel mittels Angiografie, CT oder MRT erfolgen (Schumacher G et al. Thorac Cardiovas Surg 1997; 45: 287-294, Tsubata S et al. Cardiol Youn 1998; 8: 250-252).

In diesem Fall ergab die engmaschige prä- und postnatale Überwachung durch serielle Herzuntersuchungen, dass sich die Fistel nicht vergrößerte und kein signifikanter Links-Rechts-Shunt auftrat. Es gab keine Hinweise auf eine Vergrößerung des rechten Ventrikel, der pulmonale Druck sank nach der 4. Lebenswoche auf Normalwerte ab und es lag eine restriktiven Strömung von der Fistel in den rechten Ventrikel vor. Darüber hinaus zeigte das Kind keinerlei Symptome einer Myokard-Ischämie. Daher schien es angebracht, den Verschluss der Fistel hinauszuzögern, bis das Kind ein optimales Gewicht zugelegt hatte. Abschließend ist zu sagen, dass dieser Fall einen exotischen, angeborenen kardialen Fehler aufweist, der die Leistung der detaillierten Ultraschallbewertung im Routineultraschall und der Nachverfolgung in den spezialisierten Zentren unterstreicht. Mit steigender Erfahrung, verbesserten Geräten und Techniken werden seltene, jedoch relevante kleinere fetale Anomalien entdeckt, was dazu beitragen kann, postnatale Komplikationen zu vermeiden.

\section{S. Tercanli, J. Günthard}

